\title{
Future challenges for grassland farming
}

\author{
W. PARKER \\ Science General Manager, AgResearch, Ruakura, Private Bag 3123, Hamilton \\ warren.parker@agresearch.co.nz
}

\begin{abstract}
New Zealand's grassland industries are entering a new phase of rapid technological and structural change. A complex mix of factors fuels this including institutional reform, Government science policy, growth in telecommunications, trade reform, and changes in consumer expectations and society's values towards the environment and new technology. Developing a common inspirational purpose, picking and investing in a 'best bet' future scenario, managing constraints to productivity gains, and increasing technology transfer and farmer learning are some of the challenges that those in the grassland sector must met.
\end{abstract}

Keywords: future scenarios, grassland research, land inventory, production, productivity

\section{Introduction}

In these times of relative prosperity for grassland farming it might seem surprising to be considering big changes in order to keep the sector competitive ${ }^{1}$. Most livestock farmers in 2000/01 are enjoying the best financial returns in their working lives (R. Davison pers. comm.). An uncommon combination of a low exchange rate, high commodity prices, good climatic conditions for pasture growth and a generally positive impact on demand for New Zealand product due to the BSE and foot and mouth outbreaks in the European Union (EU), have all contributed toward very good farm gate prices. However, these circumstances, while welcomed by those in agribusiness, mask substantial challenges in keeping New Zealand pastoral farming internationally competitive.

It has been known for at least a decade that New Zealand's low-cost production systems, based on comparative advantage in growing pasture and year- round grazing, have been losing ground to others who have taken up "our" grassland technologies but with even lower costs and to industrialised mega-farms whose rates of productivity improvement outpace those achieved on New Zealand farms. This does not mean that the basis of New Zealand grassland farming is wrong: rather that it needs to evolve much more rapidly than at present from commodities to take advantage of emerging and alternative high margin markets. In this paper, a range of matters pertaining to the future for grassland farming are traversed. The context for change in agriculture, future scenarios, pressures conflicting with productivity gains, and the knowledge and skill constraint are discussed.

\section{The context for rapid change}

New Zealand agriculture has been undergoing organisational and structural adjustment since the 1984 Labour Government (Sandrey \& Reynolds 1990). The pace of change has re-accelerated in the past 2 years with long-standing institutions such as the Producer Boards disappearing or being refocused ${ }^{2}$, and the further aggregation of processing ${ }^{3}$ and farm input supply companies. The e-business and world wide web phenomena have contributed to the reconfiguration (mainly shortening) of value chains and greatly enhanced farmer and agribusiness access to information. Costs and prices have both been lowered through this but, as Porter (2001) and Stokes et al. (2001) highlight, this has rarely created new value or enhanced the competitiveness of participants.

Farm size is continuing to increase but the effects of this are being moderated to some extent by land-use change (particularly to dairying and urban expansion) and, in some rural districts, resettlement (Pomeroy 1997; also see Table 4 later). The number of sheep and beef cattle farms has decreased by about $25 \%$ since $1984 / 5$ and a similar further reduction is foreseen

1 The comment of Boltger (2001) from the Swiss IMD Management School is relevant here, "It's ironic, but the more successful you are, the more likely you are to make today to conform with yesterday."

2 For example the NZ Wool Board (Wools of NZ) is expected to be disestablished by June 2002, the NZ Dairy Board will cease operations from 31 May 2002.

3 In 2001, the South Island Meat Processor PPCS gained a controlling shareholding in Richmonds Ltd., creating the likelihood of two major meat processing companies operating within New Zealand within the next 3-5 years. 
in the next decade (R. Davison pers. comm.). Onethird of current dairy farms are not expected to be in business by 2010 (Parker 1998). Fewer, and generally larger, farms will cause new rural community dynamics, an increased demand for non-family labour (e.g., Holmes \& Cameron 2001) and will impact rural services, particularly those for education and health. Most commentators anticipate that services to remote rural districts, as exemplified by the digital divide for telecommunications (Parminter 2001) and current difficulties in recruiting and retaining rural doctors, will decline relative to those available at present.

Progress towards free trade is slow (but in the right direction) and rather than a general agreement through the World Trade Organisation (WTO) it seems that free-trade agreements within regional blocks will provide for more rapid improvement in market access. In this respect, New Zealand's positioning with Australia, Singapore and Chile can potentially facilitate entry to NAFTA and this would bring enormous benefits to New Zealand. The growing lobby against globalisation lead by labour and environmental organisations may slow progress in achieving free trade and New Zealand farmers are unlikely to see significantly gains from trade reform during the next 5 years. Further, the benefits from this could be realised by countries with emerging grassland economics rather than New Zealand (Rae et al. 1998; 2001). China and India, through their population size and rapidly growing level of foreign investment, will strongly increase their influence in the world economy and food and fibre markets.

Public concerns about food safety and the environment (Christie 1998) are of growing significance to New Zealand farmers. Lapses in border biosecurity pose a high financial exposure to farmers and the quantification of the ecological footprint (Bicknell et al. 1998) of 'producer to consumer' chains ${ }^{4}$ challenge the 'clean \& green' claims of New Zealand grassland farming (Billones 2000; Campbell \& Fitzgerald 2000). Balancing strong growth in the tourism industry (3 million visitors per annum by 2010) with the need for tight biosecurity presents a stern challenge and raises questions about the 'best' balance in New Zealand's macro-economic policy. ${ }^{5}$

The role of science in defining food standards and assessing the environmental impacts of new farm technology is being questioned by powerful political lobby groups (Christie 1998). Besides protests against free trade, this is reflected by their growing agitation against the use of animals in research, antagonism toward new technologies (such as those based on genetic modification), challenges to land-owner property rights, and the imposition of "urban" norms on rural communities. Locally, the Resource Management Act and Treaty of Waitangi especially, are impacting on the options that farmers can pursue.

The global trend towards privatisation of $R \& D$ in the biosciences to capture intellectual property (IP) and competitive advantage from plants and animals has substantial implications for New Zealand agribusiness in terms of on-farm costs (royalty payments), freedom to operate and market access. It is also a clear sign that the basis of wealth generation from agriculture is rapidly changing - previously it was derived from physical assets such as land, improvements and livestock. Increasingly it will be associated with knowledge and the application of this to new products and services. A challenge for grassland farmers is, 'How do we benefit from IP (and other forms of knowledge) generated through our collective investment in research?' ${ }^{6}$

A new grassland economy in New Zealand will emerge from this dynamic of global and local change, aided by rapidly expanding and improving telecommunications ${ }^{7}$. Relative to current practice, the trends suggest it will be more technology intensive with higher levels of automation, more strongly anchored in relationships (soft touch), focused on high margin products and services (and therefore on markets with high levels of disposable income), more environmentally sustainable, perceived as more natural, and orientated toward human health and wellbeing rather than nutrition, clothing and shelter.

\section{Future scenarios for grassland farming}

Telling a 'story about the future' (Campbell-Hunt 1997) or building scenarios is a powerful technique for imagining how the future might be and for identifying

4 The EU are proposing the concept of 'food miles' as a way to describe the energy efficiency of consumer products sourced through different supply chains. Thus, New Zealand's distance to market will reappear as a new trade access challenge.

5 Some could contend that New Zealand's long-term future is not in agriculture at all, but as a "mecca" for wealthy tourists who come to view rural landscapes. This is analogous to recent developments in UK countryside management to cater for tourism and the general public rather than production agriculture. The 2001 foot-and-mouth outbreak is likely to accelerate this change.

6 An alternative view is that farmers, like other members of the community, can buy biotechnology stocks and obtain a dividend through these.

7 The telecommunications boom lead Tom Peter's (1997) to proclaim, "Distance is dead". The internet and cellular phone have radically changed the timeliness, cost and level of access to information for farmers. 
Figure 1 A simple scenario, planning framework showing elements in four possible futures for New Zealand grassland (Modified from Campbell-Hunt 1997).

\section{Open world and local market for primary products}

\begin{tabular}{|c|c|c|c|}
\hline Vegetarianism and & $\begin{array}{l}\text { Strategy A: } \\
\text { - } \quad \text { Grassland to vegetable and } \\
\text { other protein crops } \\
\text { - } \quad \text { System certification } \\
\text { - } \quad \text { Low chemical; GE free } \\
\text { - } \quad \text { Eco-energy efficient }\end{array}$ & $\begin{array}{l}\text { Strategy B: } \\
\text { - } \quad \text { Large-scale, low-cost } \\
\text { commodity production } \\
\text { - } \quad \text { Traceability and QA systems } \\
\text { - } \quad \text { Biotechnology, GM foods, crops } \\
\text { \& forages } \\
\text { - Unskilled \& skilled labour }\end{array}$ & Strong consumer \\
\hline 'natural' products & $\begin{array}{l}\text { Strategy C: } \\
\text { - Niche products } \\
\text { - } \quad \text { System certification } \\
\text { - } \text { Low chemical } \\
\text { - } \text { Cottage industry } \\
\text { - Farm tourism } \\
\text { - Highly skilled labour }\end{array}$ & $\begin{array}{l}\text { Strategy D: } \\
\text { - Highly differentiated products } \\
\text { - } \quad \text { Health \& wellbeing products; \& } \\
\text { bioactives } \\
\text { - } \text { QA \& traceability } \\
\text { - } \quad \text { Selective biotechnology \& GM } \\
\text { foods } \\
\text { - Highly skilled labour; } \\
\text { - } \text { automation } \\
\text { Shortened value chains }\end{array}$ & $\begin{array}{l}\text { milk-based } \\
\text { products }\end{array}$ \\
\hline
\end{tabular}

Regulation and high trade barriers

strategies that are most likely to succeed. Schwartz (1996), the 'father' of scenario planning, describes it as a 'strategic conversation .... which systematically raises people's understandings of their environment and of each other ... [and] allows people to act toward common ends ... [they] occur long before the moment of decision'. A simple two-axis technique for creating four future scenarios for New Zealand grassland farming is illustrated in Figure 1. Conclusions should not be drawn for any scenario until a thorough analysis and understanding of each has been developed. Two key off-farm variables that will impact grassland farming over the next 20 years are: trade liberalisation and improved market access ('free trade'), and consumer demand for animal-derived products (including nonfoods). Scenarios for other external drivers of change can be developed in the same way.

In broad terms, strategies A \& B represent 'industrialised farming, commodities, cost leadership \& process efficiency'; while strategies C \& D reflect 'high differentiation, product leadership \& customer intimacy'. Elements of scenarios are not mutually exclusive. For example, A can co-exist as the transition to $\mathrm{D}$ is made. Clearly, the research \& education investment for these scenarios are very different and this prompts the question, 'What shared inspirational dream (Gilson et al. 2000) can those involved in NZ grassland farming commit to'?

\section{Developing an inspirational dream}

A great strength of New Zealand farming has been a pioneering spirit through 'rugged individualism, hard work, determination and personal reward'. Familyowned-and-operated farms have been the cornerstone to this and the opportunity 'to buy our own farm' has been a very strong motivating goal for young people entering the industry ${ }^{8}$. These positive characteristics, however, have also acted against achieving a unity of purpose across the grassland sector: Producer Boards and other groups representing farming became "bogged down" in politics rather than the best interests of farmers; cross-sector collaboration in developing underpinning technologies has been poor; farmers became disenchanted with leadership and question the value of paying levies; and the agricultural lobby failed to seriously influence mainstream economic and agrarian policy. Thus, while agriculture continues to be a dominant export earner and has achieved superior productivity growth to most other sectors of the New Zealand economy (Johnson 1998), progress in 'reinventing' the sector to keep it ahead of competitors has been compromised.

New Zealand grassland industries are not in crisis ${ }^{9}$ but they certainly need to improve the rate of innovation by two- to three-fold to at least match

8 This is well exemplified by the sharemilking system that provided a clear career path from farm labourer to herd owner to farm owner. Sharemilking is being replaced, especially by large herd owners, with equity partnership and herd manager roles. The rate of new entrants to dairying via sharemilking (or any other pathway) has dramatically slowed. If this applies for the long term, New Zealand farm owners will on average steadily 'age' with associated impacts on the rate of on-farm innovation.

9 Peter Brabeck, CEO (Wetlauger 2001, p. 114) presents a cogent case for evolution rather than revolution. 
that of competitors. To do so requires a clear view on future targets and how current strengths (or core competencies $)^{10}$ can be built on to achieve this, including those at the farm level (Parker 2000).

Recently, progress to improve livestock industry co-ordination and collaboration has been made. The Primary Industry Council (PIC) which represents all primary industry organisations is developing, through a sub-set of the 'Livestock Boards', a shared pastoral research strategy. More work is required to develop and articulate a 'dream' that farmers can relate and aspire to, and which they will support financially (through levies) and on-farm (through technology adoption and practice change). According to the Peak Performance Organisation (PPO) model (Gilson et al. 2000), the grassland sector should define a challenge that is motivating, collectively important and able to provide a sense of recognition (e.g., attributes of this might include health, wellbeing, leading edge, safe, premium products, integrity, a small ecological footprint). Some sectors have already done a lot of work on this, including through the MoRST foresight process and their own efforts. For example, the 'dream' for the Fertiliser Manufacturers' Research Association (FMRA) for 2015 is: Every New Zealand farmer and grower has access to, and uses information about, fertiliser use in a way that meets the needs of customers, the environment and their farming business. Resource managers and policy agencies use this information to achieve best practice in nutrient information (Furness et al. 2001).

In developing and sharing an inspirational dream for grassland farming, industry leaders are going to have to reach a consensus on the future they wish to create (e.g., scenario D). They will also need to coordinate industry funding with that of the Crown to generate the portfolio of science and technology required and at the same time, provide input into the education curricula that will enable the dream to become a reality. It is not the role of researchers to formulate the dream: they should actively input to this, but industry must "own" its future and commit to its realisation.

\section{Implications for science}

The McKinsey Reports on the dairy and wool industries (McKinsey 2000) prescribed targets for on-farm productivity gains of 4 and $5 \%$ per annum, respectively.
These far exceed the traditional rates of gains made in most areas of pastoral farming over the past decade (Table 1), although on an aggregate basis, Johnson (1999) showed that New Zealand agriculture's total factor productivity (TFP) averaged 4.5\% between 1972 and $1992^{11}$.

Table 1 Physical productivity trends (1990-91 to 2000-01) for the New Zealand pastoral industries (Davison 2001 MWBES).

\begin{tabular}{lc}
\hline Productivity per head (av). & Per year \\
\hline Lamb (kg/sheep) & $+3.2 \%$ \\
Milkfat (/cow) & $+0.8 \%$ \\
Wool $(\mathrm{kg} / \mathrm{sheep})$ & $+0.7 \%$ \\
Beef $(\mathrm{kg})$ & $-0.1 \%$ \\
\hline
\end{tabular}

Research must therefore adopt a portfolio that includes more projects with the potential for "quantum" gains. Since Crown funding of R\&D to the productive sector has been contracting in real terms, and research investment is not yet significant in the private sector (typically less than $0.5 \%$ of farm-gate returns), it is logical that Government funds should be reallocated ("advanced" in FoRST parlance) from "efficiency/ productivity" research to the "new" areas in order to develop new wealth-generating enterprises as illustrated in Figure 2. The corollary is that science capability in the Crown Research Institutes (and Universities) is being repositioned to drive knowledge discovery and wealth creation for primary production in a new direction. Venture capital funding is being promoted for this reason too and to encourage stronger relationships between research providers and end-users of technology and services.

Unless existing and emerging industries share the same aspirations and strategies and are committed to their implementation, this change process will fail. It is most important too, given New Zealand's small economy and science workforce, that collaboration between research, education and end-users is fostered. Lessons from the 1990s when three major changes in Crown science policy together with high compliance costs, compromised science productivity, eroded workforce morale and promoted survival rather than risk-taking, should not be forgotten either. There is a particular need to ensure the applied and integrative capabilities, a major strength of New Zealand science,

10 Hamel \& Prahalad (1994) proposed that strategy should be based on a firm's 'core competence' or an integrated set (or bundle) or skills and technologies (e.g., grazing management and electric fencing equipment).

11 Johnson (1998) demonstrated that agriculture has consistently been the best or near to best performer of sectors in the New Zealand economy. He laments the failure of Crown officials to use this information to argue the case for increased investment in agriculture. In 2001 the politicians' perspective of the future role of the animal and plant industries in New Zealand's future has become more supportive. 
Figure 2 Opportunities for new business in the grassland sector (WoNZ Strategic Plan 1999).

New business creation

... integrating marketing and technology

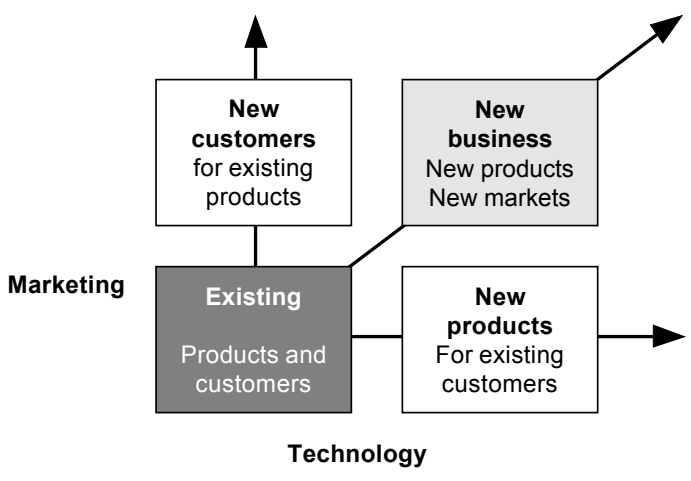

are sustained as Crown funds are reinvested in strategic (options) and public benefit research. Parallel investment and change must be made in education to generate the knowledge and skills required in the future grassland workforce ${ }^{12}$.

Scientists and technologists work in an international market. Their expertise is readily transferable between laboratories and organisations. Most OECD nations are sharply increasing their investment in $R \& D$, particularly in the life sciences (e.g., Singapore will invest $\$ S 1$ billion in life sciences over the next 5 years and molecular biologists, often 'head hunted' from offshore, are now amongst the highest paid members of the workforce. Likewise, Australia has plans to sharply increase its expenditure on $R \& D$ and is further developing policies to encourage private sector investment in R\&D so that it is in the top echelon of the OECD (Brenchly 2001)). New Zealand will need to respond similarly if it is to continue to retain and attract the 'best' science minds that are critical to driving grassland innovation. A more proactive policy framework to encourage private sector investment is required.

\section{Productivity and profitability}

The distinction between production (total output) and productivity (output:input or efficiency) must be understood by farmers and researchers if New Zealand grassland's competitiveness is to be improved. Gains in efficiency are achieved when the rate of change in output exceeds the rate of change in input - that is, "more is obtained for less". Farm productivity gains can also be measured as Total Factor Productivity
(TFP) as illustrated for sheep farming by Figure 3. The top line reflects the quantities of farm output and their value, the bottom line the cost of farm inputs for production including capital and the reward for the farmer's labour and management. Also, adjustments are made for changes in inventory (e.g., bales of hay in storage) and livestock numbers (e.g., extra hoggets carried over) to prevent between-year anomalies in farm income and costs. To increase productivity the items of the top line have to increase faster than the combined increase for items on the bottom line. The TFP points to areas where R\&D and extension can be best focused to achieve the target rates of gain.

Figure 3 Elements in a sheep farm Total Factor Productivity equation (derived from Pringle 2000).

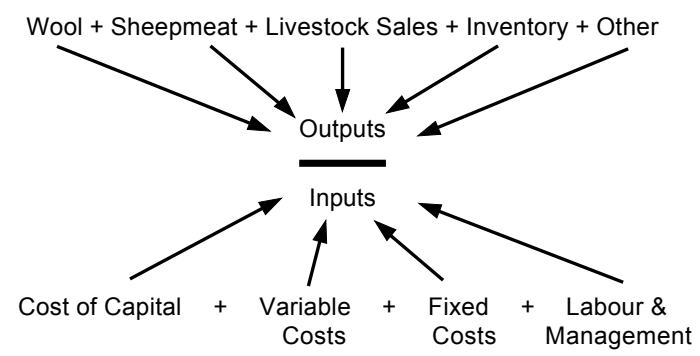

The traditional response by farmers to declining real prices for agricultural commodities has been to increase production, primarily by scaling-up their current business. Except for labour, and in some cases capital, economies of size (effectively gains in efficiency) seem rarely to have been realised in dairying (Leslie 1998; Parker 1998) and probably not in the other livestock sectors as well. The consequence of production growing faster than market demand (and the rate of product innovation) has been to erode farmgate returns, especially where earnings have had to be retained to build new processing capacity for the extra volume of production. Two examples point to a future pathway for the grassland sector overall. Firstly, the Tatua Dairy Company, which has limited milk volume growth to existing suppliers and vigorously pursued product innovation, and secondly, the sheep industry where a $40 \%$ reduction in sheep numbers has been compensated by an improved lambing percentage, heavier carcass weights, increased processing and logistics efficiency, further processing to higher cuts and improved marketing (Davison 2001) (Table 1).

The inclusion of the 'cost of capital' in the TFP has caused consternation amongst dairy farmers. In

12 See Holmes \& Cameron (2001) for an outline of future on-farm needs in the dairy industry. 
simple terms, a farm business creates value (wealth) for its owner(s) if the Net Operating Profit after Tax (NOPAT) is greater than the weighted average cost of capital (WACC) (Shadbolt 2000). Farmers should seek to manage their business to exceed the annual cost of capital but as illustrated by Rhodes et al. (2000) for sheep and beef cattle farming and for dairying by Rawlings (1999) this is often not the case. This points to a fundamental problem for New Zealand pastoral farmers: they are over-capitalised relative to the value of production (and competitors). Of course this is not a new problem for agriculture where rates of return on assets of $3 \%$ or less per annum have routinely been accepted (Nartea \& Pellegrino 1998). It will be a growing problem for farm owners (and New Zealand because of its heavy reliance on agricultural exports), as world trade barriers are reduced and competitors with lower capital costs and similar operating efficiency enter 'our' food and fibre markets (as illustrated by Rae 2001) and because it builds an increasing barrier to new (young) entrants to the industry.

Farmers understandably resist the 'NOPAT-WACC' concept, because growth in asset value, often completely independent of productivity gains, has occurred in New Zealand farming since the 1970s (Nartea \& Pellegrino 1998). Capital gains are realised at the point of sale, although they can be used to assist farm business growth by leveraging greater debt on increases in equity. Because a capital gains tax is politically unpalatable, the best option going forward is for farmers to distinguish between their production and property business (Shadbolt 2000) and apply appropriate measures for monitoring progress in both. Time will tell whether this passive approach will change farmer investment behaviour but the sharp increase in land prices during 2000/01 as returns have improved shows that "old economy" thinking persists.

\section{Constraints to productivity and production gains}

The productivity drive in grassland farm will be moderated by constraints (Table 2). Improving TFP is therefore not a simple matter of optimising the elements in Figure 3: its optimisation is subject to factors such as sustainable resource management, freedom to exercise property rights and community acceptance.

The constraints to productivity and production gains can be considered in relation to the national land inventory (Table 3). Over the past decade, grassland has been retired to forestry, urban development, and on-farm conservation (e.g., woodlots, riparian strips).
Table 2 Growth elements and constraints in grassland's future development.

\begin{tabular}{ll}
\hline Growth elements & Growth constraints \\
\hline Productivity & $\begin{array}{l}\text { Sustainable resource use (nutrient } \\
\text { budgeting; soil quality) }\end{array}$ \\
$\begin{array}{l}\text { Carbon tax ('Kyoto protocol') } \\
\text { Property rights }\end{array}$ & $\begin{array}{l}\text { Water quality \& allocation of rights to } \\
\text { access }\end{array}$ \\
Profitability/cashflow & $\begin{array}{l}\text { Competition for skilled labour } \\
\text { Skilled people }\end{array}$ \\
New products (\& services) & $\begin{array}{l}\text { Legislation (Treaty of Waitangi (1840), } \\
\text { RMA (1991)) }\end{array}$ \\
Capital for processing & $\begin{array}{l}\text { Ownership or freedom to use IP } \\
\text { Farmers' attitude }\end{array}$ \\
\hline
\end{tabular}

Also, enterprise substitution within grassland has occurred, especially from sheep and beef cattle to dairying. Overall, the grassland area is estimated to have declined by 1,140,000 ha since 1992/3. If new horticulture (including wine) and exotic plantation plantings continue being established at 25,000 ha per annum, respectively over the next decade, the area in grassland will further reduce to $12.2 \mathrm{~m}$ ha.

Table 3 New Zealand's land inventory ( $m$ ha) and changes in grassland use (New Zealand Year Book 2000; NZ Meat Board 1993).

\begin{tabular}{lcccc}
\hline Land use & $1982-83$ & $1992-93$ & $1999-00^{\mathrm{a}}$ & $2009-10^{\mathrm{a}}$ \\
\hline Grassland including: & 14.66 & 13.84 & 12.70 & 12.20 \\
- Dairy & 1.25 & 1.46 & 2.00 & 2.30 \\
- Sheep \& beef cattle & 6.81 & 10.19 & 9.81 & 9.31 \\
- Deer & 0.05 & 0.18 & 0.29 & 0.35 \\
Horticulture & 0.03 & 0.09 & 0.14 & 0.19 \\
Plantation & 0.96 & 1.30 & 1.95 & 2.20 \\
Other & $5.61^{\mathrm{b}}$ & $2.26^{\mathrm{b}}$ & 1.80 & 1.80 \\
Total usable & 21.26 & 17.49 & 16.59 & 16.39 \\
Mountains, lakes, parks & 5.23 & 9.00 & 9.90 & 10.10 \\
TOTAL NEW ZEALAND & 26.50 & 26.50 & 26.50 & 26.50 \\
\hline
\end{tabular}

The 1999-2000 and 2009-2010 values are estimates from the New Zealand Year Book (2000) and NZMWBES information (Davison 2001, pers. comm.). This includes idle land and the effects of a change in definition between the years.

A national livestock inventory, and thus national production, can similarly be forecast as in Table 4 . Tables $3 \& 4$, combined with Figure 3 show that while production gains will be significant in dairy and deer, real value creation will need to be derived from an aggressive 'new product - new business' strategy (Figure 2). The beef industry will be heavily dependent on dairying for its growth but has prospects for onshore growth through tourism. Industry must send clearer price signals on the marginal value of production than in the past to ensure that farmers respond to market opportunities (and in this respect seasonal, even monthly, pricing of milk is anticipated in the shortterm). Investment into product and market development is now a priority and therefore, high demand on capital for specialised processing facilities is required. It is 
unlikely that farmers will be able or want to fund all of this and greater use of 'external' capital will be necessary.

Table 4 New Zealand grassland output from livestock in 1999-2000 and estimates for 2010 (Statistics New Zealand, NZMWBES reports, author's estimates).

\begin{tabular}{|c|c|c|c|c|}
\hline Livestock category & m & $\begin{array}{l}\text { 999-2000 -------- } \\
\text { Production }\end{array}$ & m & $\begin{array}{c}\text { 009-2010 -------- } \\
\text { Production }\end{array}$ \\
\hline Dairy cows & 3.337 & 970,000 t MS & 4.600 & $1,472,000$ t MS $^{a}$ \\
\hline Breeding ewes & 30.364 & 407,896 t lamb & 31.348 & $467,380 \mathrm{t} \mathrm{lamb}^{\mathrm{b}}$ \\
\hline Wool (greasy) & & $225,000 \mathrm{t}$ & & $195,500 \mathrm{t}$ \\
\hline $\begin{array}{l}\text { Deer - venison } \\
\text { - velvet }\end{array}$ & 1.676 & $\begin{array}{c}22,310 \mathrm{t} \\
450 \mathrm{t}\end{array}$ & 2.100 & $\begin{array}{c}38,000 t \\
842 t\end{array}$ \\
\hline Beef breeding cows & 1.457 & $587,000 \mathrm{t}$ & 1.244 & - \\
\hline
\end{tabular}

a Based on 2.0 cows per hectare, $320 \mathrm{~kg} \mathrm{MS}$ per cow.

Assumptions for lamb: $120 \%$ lambing, $17.5 \mathrm{~kg}$ carcass weight, $71 \%$ slaughtered.

the status quo (i.e., they were not direct users of state extension services and have not adopted a private alternative). Increased business management capability for farmers is a particular need (Stantiall 1999). Australian research indicates older, less formally educated farmers, and men, are less likely to attend training in business management than younger, formally educated and women colleagues (Murray-Prior et al. 2000). Kilpatrick et al. (1999) found farmers prefer to learn about business management and marketing on a 'one-on-one' basis and from experts. This, and other evidence (Stantiall 1999), indicates that the traditional models of industry-funded extension (for example, the farm

\section{Technology transfer and farmer learning}

Despite the degree and rate of change required in technology innovation and adoption, the farmer and his/her management skills (and those of farm staff) will remain a dominant driver of farm business success. Their transformation from skilled production managers to experts in farm systems management (value chain, people, the environment, as well as production) arguably poses the greatest challenge in securing the advances required in grassland farming. Working harder and doing more is not a sustainable solution for them: they will require practice change in management; a better support infrastructure to provide timely and relevant information for decision-making; greater levels of automation of production-tasks; real-time and predictive monitoring of system performance; new arrangements for labour (including equity sharing and outsourcing) and a sustained motivation to make continuous improvements. Farmers are likely to become far less collegial in sharing proprietary information with peers than at present. The issues of capital gains and capital efficiency will need to be addressed, and more leasing of land than at present can be anticipated.

New Zealand agriculture and science providers has yet to fully reconcile the impacts of privatisation of State-funded extension services, let alone meet these new technology transfer and farmer-learning challenges. Scientists are not, in the main, trained in extension, neither are they adequately funded to undertake the level of extension the farming community continues to expect of them. The farmer response to privatisation continues to be mixed: the "self-starters" have sought out and purchased the information they need for their farm business; many attend the much larger array of field days, conferences and special events that were not available a decade ago; others continue to operate discussion groups run by the LIC (now Dexcel) Consulting Officers) cannot invoke the rate of productivity improvement necessary to sustain industry competitive advantage. Farmer learning must be broadened from the production and Economic Farm Surplus focus that dominated extension activities to the mid-1990s, to also incorporate environmental management. Approaches to extension, technology adoption and farmer learning are therefore going to have to evolve rapidly, and given the industry's need to achieve an aggregate productivity target (i.e., an industry good outcome), farmers will be asked to support extension (social sciences) research and activities via a levy. This may not be popular with self-motivated farmers who organise their own learning.

\section{Concluding comments}

New Zealand's grassland industries are entering a period of rapid technological and structural change. A complex mix of factors fuels this including institutional reform, Government policy, growth in telecommunications, trade reform, and changes in consumer expectations and society's values towards the environment and new technology. Change presents problems, and new opportunities. Farmers as they have in the past, will eagerly seek to solve and realise these. They will look to 'grassland' scientists to increase the pace of innovation. Scientists, however, will have a difficult job in meeting productivity targets and accelerating product innovation two- to threefold, unless farmers and industry elect to pay a similar-fold increase in levies to support an associated portfolio of research. A shared, and inspiring, 'dream' for grasslands will build farmer confidence to do so, and increase their commitment to making the practice changes and taking-up of new technology necessary 
to sustain competitive advantage. Increasing the proportion of high margin products from plants and animals must be integral to this. Leadership across the livestock industries, and science and education communities, will be key to making a shared 'dream' a reality. Tension will increase in balancing farmer property rights with those of the wider community and in intensifying production without compromising environmental standards. However, New Zealand agriculture has demonstrated in the past strong resilience and determination to overcome economic recession and climatic disasters. The current challenges for growth and innovation can therefore be met with confidence.

\section{REFERENCES}

Bicknell, K.R.; Ball, R.J.; Cullen, R.; Bigsby, H.R. 1998. New methodology for the ecological footprint with an application to the New Zealand economy. Ecological Economics 27: 147-160.

Billones, R. 2000. Consumer and farmer perceptions of the New Zealand dairy industry's image. Master of Applied Science Thesis, Massey University.

Boltger, P. 2001. Quoted in Mt Eliza Business News, Issue 8: 2.

Brenchley, F. 2001. President Kim. The Bulletin (August 21): 20-21.

Campbell, H.; Fitzgerald, R. 1998. New Zealand food exports in the $21^{\text {st }}$ century: whither the green option? Proceedings of the New Zealand Society of Animal Production 60: 72-77.

Campbell-Hunt, D. 1997. Scenarios and strategic thinking. Proceedings of the Primary Industry Conference (Palmerston North): 122-126.

Christie, R. 1998. Food markets of the future. Proceedings of the New Zealand Society of Animal Production 60: 78-82.

Davison, R. 2001. Is there room to move? Sector performance and benchmarking, Canterbury Sheep Council Annual Meeting.

Gilson, C.; Pratt, M.; Roberts, K.; Weynes, E. 2000. Peak performance: Business lessons from the world's top sports organizations. Harper Collins Business.

Furness, H.; Manning, M.; Johnston, T. 2001. Industry research: future options. Proceedings FMRA Annual Conference 110-117.

Hamel, G.; Prahalad, C.K. 1994. Competing for the future. Harvard Business School Press, New York.

Holmes, C.W.; Cameron, K. 2001. High merit 'people replacements', the foundation of future success on dairy farms. Dairy Farming Annual, Massey University 53 (in press).
Johnson, R. 1999. The contribution of agriculture to the national economy of New Zealand. Paper presented to Annual Conference of Australian Agricultural \& Resource Economics Conference, Christchurch, New Zealand.

Kilpatrick, S.; Johns, S.; Murray-Prior, R.B. 1999. Managing farming: how farmers learn. Publication No. UT-18a, Rural Industries and Development Corporation, Barton, ACT.

Kreigel, R.J.; Brandt, D. 1996. Sacred cows make the best burgers. Pymble, NSW, Harper Business.

Leslie, M. 1998. Profitability of farms less than 60 hectares. Dairy Farming Annual, Massey University 50: $31-42$.

McKinsey 2000. Report to Woolgrowers, McKinsey Co., Auckland.

Murray-Prior, R.B.; Hart, D.; Dymond, J. 2000. An analysis of farmer uptake of farm management training in Western Australia. Australian Journal of Experimental Agriculture 40: 557-570.

Nartea, G.V. Pallegrino, J. 1997. Risk-return characteristics of farmland and their implication for land valuation. Proceedings of the Primary Industry Conference (Palmerston North): 165-172.

New Zealand Year Book 2000. Government Printer, Wellington.

New Zealand Meat Board 1993. Strategic plan 1993 2000. New Zealand Meat Board, Wellington.

New Zealand Meat \& Wool Boards' Economic Service. Various Annual Reports, NZMWBES, Wellington.

Parker, W.J. 1998. The future of the small dairy farm. Dairy Farming Annual, Massey University 50: 43-56.

Parker, W.J. 2000. Principles of successful business management. Proceedings of the International Large Herds' Conference (Christchurch): 60-68.

Parminter, I. 2001. E-commerce and the primary sector. Rural Bulletin, MAFPolicy, Wellington (August): 8-9.

Peters, T. 1997. The circle of innovation. Hodder \& Stroughton, London.

Pomeroy, A. 1997. Impacts of recent economic reforms on rural communities. AERU Discussion Paper No. 145: 1-10.

Porter, M. 2001. Strategy and the internet. Harvard Business Review (March): 63-78.

Pringle, R. 2000. Centre of Excellence to focus on 4\% target. New Zealand Dairy Exporter (September) 76 (2): 84-85.

Rae, A.N. 2001. The role of grasslands in world food trade: Some projected impacts of future trade policy reforms. New Zealand Journal of Agricultural Research (submitted).

Rae, A.N.; Nixon, C.; Gardiner, P. 1998. Foot-andmouth disease and trade restrictions: Latin 
American access to Pacific Rim beef markets. $A E R U$ Discussion Paper No. 146: 181-187.

Rawlings, K.M. 1999. Key performance indicators for goal attainment in dairy farming: essential elements for monitoring farm business performance. MApplSc Thesis, Massey University.

Rhodes, T.; Willis, B.; Smith, W. 2000. Impediments to optimising the economic and environmental performance of agriculture. A study of issues affecting North Island hill country farmers. $M A F$ Policy Technical Paper 2000/17, Wellington.

Sandrey, R.; Reynolds, R. 1990 (eds.) Farming without subsidies: New Zealand's recent experience. MAF and GP Books, Wellington.
Shadbolt, N.M. 2000. Achieving business growth within a new industry structure. Proceedings International Large Herds' Conference (Christchurch): 84-90.

Stoke, M.; Nixon, C.; Parminter, I. 2001. E-commerce in the primary sector: Spectre or saviour? MAF Policy Research Paper, Wellington, New Zealand.

Stantiall, J. D. 1999. Facilitating learning: Enhancing dairy farmer competence through workshops. MApplSc Thesis, Massey University.

Schwartz, P. 1996. The art of the long view. First Australian Edition, Australian Business Network.

Wetlaufer, S. 2001. The business case against revolution: An interview with Nestle's Peter Brabeck. Harvard Business Review (February): 113-119.

WoNZ 1999. Strategic plan. Insert to NZ Farmer (May). 